\title{
RELATION OF LACTOBACILLI ACIDOPHILUS TO NON- ALCOHOLIC FATTY LIVER IN A SAMPLE OF EGYPTIAN POPULATION
}

\author{
Magda Shokry Mohamed ${ }^{1}$, Yara Mohamed Eid ${ }^{1}$, Doaa Zakaria Zaky ${ }^{2}$ Kamal \\ Mohie El-din Selim ${ }^{3}$, Nagwa Roshdy Mohamed $^{4}$
}

\begin{abstract}
${ }^{1}$ Departement of Internal Medicine \& Endocrinology, and ${ }^{2}$ Tropical Medicine, Faculty of Medicine, Ain Shams University, Cairo, Egypt. And Department of internal medicine, Desouk fever hospital, Kafr Ashaykh, Egypt

Corresponding Author: Nagwa Roshdy Mohamed Mobile: (+2) 01065958431

E-mail:

dr_pharos2000@yahoo.com Received: $23 / 7 / 2020$

Accepted: 17/8/2020
\end{abstract}

Online ISSN: 2735-3540

\begin{abstract}
Background: Non-alcoholic fatty liver disease (NAFLD) is an insidious disease, which leads to the deposition of lipid within the hepatic parenchyma. It affects different age groups in Egyptincluding children. Its degree of severity range from steatosis to nonalcoholic steatohepatitis (NASH), which later could progress into lifethreatening diseases such as cirrhosis and hepatic malignancy. Progression towards inflammation of the steatotic liver was initially proposed to be related to endotoxemia as a result of increased gut permeability. Subsequently, there is some evidence that intestinal microbiota plays an important part in the pathogenesis of NAFLD.
\end{abstract}

Aim of the work: To detect possible relation of lactobacillus acidophilus to non-alcoholic fatty liver disease in a sample of Egyptian population.

Patients and methods: The current study included 60 subjects. They were divided in to Group 1: included 20 obese subjects with NAFLD; Group 2 :included 20 lean subjects with NAFLD; Group 3: included 20 healthy subjects as a control group. Identification of stool lactobacillus acidophilus by quantitative real time PCR technique and abdominal ultrasound for diagnosis of NAFLD.

Results: There was non significant difference between studied groups as regard lactobacillus acidophilus concentration in stool $P=0.986$. There was non significant elevation of ALT and AST in NAFLD obese subjects in positive PCR group compared to other groups

Conclusions: Still there is controversy about the role of lactobacillus acidophilus in the pathogenesis of NAFLD

Keywords: Obese, NAFLD, lactobacillus acidophilus

\section{INTRODUCTION:}

Non-alcoholic fatty liver disease (NAFLD) tops the list of etiologies of hepatocellular carcinoma; it affects about $25 \%$ of adults worldwide ${ }^{[1]}$. In 2014, the estimated hospital-based prevalence of NAFLD among children and adolescents in Egypt was about $15.8 \%{ }^{[2]}$. It is an insidious disease, affecting different age groups in Egypt. Several risk factors incorporated in its pathogenesis, including advanced age and hyperlipidemia, besides the roles of proand/or anti-inflammatory cytokines ${ }^{[3]}$. Its degrees of severity range from steatosis or non-alcoholic steatohepatitis (NASH) with/ without fibrosis to life-threatening diseases such as cirrhosis and hepatic malignancy ${ }^{[4]}$.

Microbiota is the group of microorganisms containing two main phyla: Bacteroidetes and Firmicutes that live within 
and on each mammal. It has a role in metabolic processes, drug metabolism, growth and development, maintenance of gastrointestinal tract integrity, and immune response. Its composition is in continuous modifications, which is influenced by multiple environmental factors, hormonal, nutrition, immune status, genetics, and epigenetics ${ }^{[5,6]}$. The pathologic modification of microbiota termed dysbiosis could yield several diseases such as metabolic syndrome, obesity, diabetes, cardiovascular diseases and lately NAFLD ${ }^{[7]}$. Accordingly, studying and identifying the underlying mechanism by which microbiota induces NAFLD was a topic of interest. Some of the suggested mechanisms include dysregulation of the gastrointestinal barrier, shortchain fatty acid release, appetite, and the endocannabinoid system, besides impairment of choline and bile acid metabolism ${ }^{[8]}$.

There is a paucity of studies that assessed the hypothesis of modification of gut microbiota in correlation NAFLD pathogenesis ${ }^{[9]}$. In our study, we assessed this hypothesis in order to support or reaching a consensus in this regard and boost published evidences. Consequently, this could floor a path for more swift and rapid detection of the insidious disorder NAFLD and the usage of promising probiotics therapies.

\section{PATIENTS AND METHODS:}

A case-control study conducted on 60 subjects attending the Endocrine Clinic at the Ain-Shams University Hospital in Egypt between March 2017 and February 2018. Their age ranging between 20 and 70 years old. Before inclusion, an oral consent was obtained from each participant after full explanation of the study.

Inclusion criteria: subject's age was ranging from 20 to 70 years old; they were divided into group 1: 20 obese subjects with NAFLD, group 2: 20 lean subjects with
NAFLD, group 3: 20 healthy subjects of comparable age and sex as a control group who were recruited from patients' companions and relatives. Diagnostic criteria of NAFLD, according to Chalasani et al., ${ }^{[10]}$ : I) No or minimal alcohol use (ranged from $\leq 1$ drink $(14$ to $<30)$ grams per day on average) II) Absence of other causes for liver disease, III) No secondary causes of NAFLD such as medications and dyslipedemia,

Exclusion criteria: Patient with liver cirrhosis or positive findings for viral hepatitis markers antibody to HCV (HCV$\mathrm{Ab}$ ) and HBs antigen (HBsAg), history of excess alcohol consumption, inflammatory bowel disease, type 1 and 2 diabetes mellitus. Full detailed medical history and thorough clinical examination including measurement of body mass index $(\mathrm{BMI})\left(\mathrm{kg} / \mathrm{m}^{2}\right)$.

\section{Laboratory investigations:}

Serum alanine (ALT) aminotransferase, aspartate (AST) aminotransferase method: colorimetric determination of ALT and AST activities was performed according to Berg Meyer and Horder using a kit obtained from the Human Company (Germany), Serum level of gamma-glutamyl transferase (GGT) by enzymatic colorimetric color trick method, $\mathrm{HCV}-\mathrm{Ab}$ and $\mathrm{HBs} \mathrm{Ag}$ by ELISA Fasting blood glucose (FBG) after eight hours overnight fasting and two hours postprandial blood glucose by enzymatic hexokinase determination using the kit supplied by Stanbio Laboratory (USA), ${ }^{[11]}$, Glycated hemoglobin (HBA1C): analyzed by using kit No. 0350 from Stanbio Laboratory (USA) method: quantitative colorimetric determination of glycated hemoglobin (HbA1C) ${ }^{[12]}$, Serum lipid profile: total cholesterol, highdensity lipoprotein (HDL), low-density lipoprotein (LDL) and fasting triglycerides using kits were acquired from Stanbio laboratory in the United States, serum total cholesterol and serum triglyceride were 
analyzed by an enzymatic colorimetric technique ${ }^{[13]}$, HDL-cholesterol was determined by ultracentrifugation ${ }^{[14]}$, and LDLcholesterol results was obtained by Friedewald calculation ${ }^{[15]}$. Detection of lactobacillus acidophilus in a stool sample using semi-quantitative real time PCR technique ${ }^{[16]}$.

\section{Radiological investigation:}

Abdominal ultrasound used to diagnose NAFLD; the device used was Sono Ace R5 (6 MHz; Samsung). Characteristic features of NAFLD include bright hepatic echoes, increase hepatorenal echogenicity and presence of the vascular clouding of a portal or hepatic vein ${ }^{[17]}$. Of note, NAFLD is characterized by the presence of blurring of the portal or hepatic vein besides high liver and kidney echogenicity ${ }^{[18]}$.

\section{Statistical methods:}

Data analysis was performed by using IBM SPSS statistics (Statistical Package for Social Sciences) software version 18.0, IBM Corp., Chicago, USA, 2009. We analyzed qualitative outcomes as number and percentage; however, quantitative outcomes with normal distribution was analyzed as minimum and maximum of the range together with mean \pm standard deviation (SD). The Pearson correlation coefficient (r) was used for the parametric correlation coefficient in order to determine the association between normally distributed continuous variables. For two independent groups with quantitative data, we used the ttest; however, the ANOVA test with post hoc Tukey test was used for more than two independent groups. For qualitative data, we used the Chi-square test to estimate differences between proportions and considered Fisher's Exact for data with a small sample size.Probability p-value) less than 0.05 was considered significant and less than 0.01 was considered as highly significant.

\section{RESULTS:}

Our study was conducted on 60 subjects. We divided them into the following three groups: Group 1: included 20 obese subjects with NAFLD; 10 subjects were males $(50.0 \%)$, and 10 subjects were females $(50.0 \%)$. Their mean age was $(34.9 \pm 7.2)$ years old, and the mean BMI was $(32.3 \pm 1.9)$ $\mathrm{kg} / \mathrm{m}^{2}$, BMI was significantly higher among NAFLD obese group compared to other both groups ( $\mathrm{P}<0.001$ ). With no significant difference between NAFLD lean and control groups . The semi quantitative PCR for lactobacillus acidophilus was positive in $75 \%$ of subjects in this group.

Group 2: Included 20 lean subjects with NAFLD; 13 subjects were males $(65.0 \%)$, and7 subjects were females $(35.0 \%)$. With their mean age was $(36.6 \pm 7.5)$ years old, and the mean BMI was $(23.2 \pm 1.0) \mathrm{kg} / \mathrm{m} 2$. The semi-quantitative PCR for lactobacillus acidophilus was positive in $70 \%$ of subjects in this group. Group 3: Included 20 healthy subjects as control group lean without fatty liver; 9 subjects were males (45.0\%), and 11 subjects were females $(55.0 \%)$. With their mean age were $(35.3 \pm 8.4)$ years old, and the mean BMI was $(22.9 \pm 1.3) \mathrm{kg} / \mathrm{m} 2$. The semiquantitative PCR for lactobacillus acidophilus was positive in $60 \%$ of subjects in this group.

There was non significant difference between subjects with positive and negative PCR in the 3 studied groups regarding sex, age and BMI.

There was non significant difference between studied groups as regard lactobacillus acidophilus concentration in stool (table 1) $\mathrm{P}=0.986$. There were significant elevation of FBG, 2Hpp, HbA1c and lipid profile in NAFLD obese group compared to control group (table2).

There was no significant difference among subjects with positive and negative PCR regarding liver enzymes in the 
3studied groups (table 3). There was non significant correlation between the cycle threshold PCR of lactobacillus acido- philus and age, BMI, liver enzymes and lipid profile in the NAFLD obese group (table 4)

Table (1): Lactobacillus Acidophilus detection by quantitative real time PCR technique between the studied groups

\begin{tabular}{|c|c|c|c|c|c|}
\hline Variables & Measures & $\begin{array}{l}\text { NAFLD } \\
\text { obese } \\
(\mathrm{N}=20)\end{array}$ & $\begin{array}{l}\text { NAFLD lean } \\
(\mathrm{N}=20)\end{array}$ & $\begin{array}{l}\text { Control } \\
(\mathrm{N}=20)\end{array}$ & $\mathrm{P}$ \\
\hline \multicolumn{2}{|l|}{ Positive PCR (n, \%) } & $15(75.0 \%)$ & $14(70.0 \%)$ & $12(60.0 \%)$ & $\# 0.583$ \\
\hline Cycle threshold & Mean \pm SD & $35.6 \pm 5.8$ & $35.5 \pm 8.1$ & $35.8 \pm 8.2$ & $\wedge 0.986$ \\
\hline
\end{tabular}

$\wedge$ ANOVA test, \#Chi square test

Table (2): Metabolic findings among the studied groups

\begin{tabular}{|c|c|c|c|c|c|}
\hline Variables & Measures & $\begin{array}{c}\text { NAFLD } \\
\text { obese } \\
(\mathrm{N}=20)\end{array}$ & $\begin{array}{c}\text { NAFLD } \\
\text { lean } \\
(\mathrm{N}=20)\end{array}$ & $\begin{array}{l}\text { Control } \\
(\mathrm{N}=20)\end{array}$ & $\mathrm{P}$ \\
\hline \multirow{2}{*}{$\begin{array}{l}\text { FBG } \\
(\mathrm{mg} / \mathrm{dL})\end{array}$} & Mean \pm SD & $89.0 \pm 6.9$ & $88.1 \pm 6.5$ & $83.9 \pm 6.6$ & \multirow{2}{*}{$\begin{array}{l}\wedge \\
0.040 *\end{array}$} \\
\hline & HG & $\mathrm{b}$ & $\mathrm{ab}$ & $\mathrm{a}$ & \\
\hline \multirow{2}{*}{$\begin{array}{l}2 \mathrm{hrs} \text { PPBG } \\
(\mathrm{mg} / \mathrm{dL})\end{array}$} & Mean \pm SD & $119.2 \pm 9.8$ & $116.3 \pm 11.4$ & $110.3 \pm 10.5$ & \multirow{2}{*}{$\hat{0.032 *}$} \\
\hline & HG & $\mathrm{b}$ & $a b$ & $\mathrm{a}$ & \\
\hline \multirow{2}{*}{$\begin{array}{l}\text { HbA1c } \\
(\%)\end{array}$} & Mean \pm SD & $5.3 \pm 0.1$ & $5.3 \pm 0.2$ & $5.1 \pm 0.3$ & \multirow{2}{*}{$\hat{0} .007 *$} \\
\hline & HG & $\mathrm{b}$ & $\mathrm{ab}$ & $\mathrm{a}$ & \\
\hline \multirow{2}{*}{$\begin{array}{l}\text { S. total Choles-terol } \\
(\mathrm{mg} / \mathrm{dL})\end{array}$} & Mean \pm SD & $184.5 \pm 46.1$ & $167.4 \pm 41.4$ & $148.2 \pm 17.8$ & \multirow{2}{*}{$\begin{array}{l}\wedge \\
0.012 *\end{array}$} \\
\hline & HG & $\mathrm{b}$ & $\mathrm{ab}$ & $\mathrm{a}$ & \\
\hline \multirow{2}{*}{$\begin{array}{l}\text { S.Triglyc-erides } \\
(\mathrm{mg} / \mathrm{dL})\end{array}$} & Mean \pm SD & $163.1 \pm 61.0$ & $149.6 \pm 41.1$ & $127.5 \pm 18.5$ & \multirow{2}{*}{$\hat{0} 0.042 *$} \\
\hline & HG & $\mathrm{b}$ & $\mathrm{ab}$ & $\mathrm{a}$ & \\
\hline \multirow{2}{*}{$\begin{array}{l}\text { S. LDL choles-terol } \\
(\mathrm{mg} / \mathrm{dL})\end{array}$} & Mean \pm SD & $137.4 \pm 50.1$ & $118.0 \pm 47.5$ & $90.9 \pm 17.9$ & \multirow{2}{*}{$\hat{0.003 *}$} \\
\hline & HG & $\mathrm{b}$ & $\mathrm{ab}$ & $\mathrm{a}$ & \\
\hline \multirow{2}{*}{$\begin{array}{l}\text { S. HDL choles-terol } \\
(\mathrm{mg} / \mathrm{dL})\end{array}$} & Mean \pm SD & $47.7 \pm 9.8$ & $49.9 \pm 10.3$ & $57.4 \pm 1.4$ & \multirow{2}{*}{$\begin{array}{l}\wedge \\
<0.001 *\end{array}$} \\
\hline & HG & $\mathrm{b}$ & $\mathrm{b}$ & $\mathrm{a}$ & \\
\hline
\end{tabular}

^: ANOVA test with post hoc Tukey test, \#: Chi square test, *: Statistically Significant at $p \leq 0.05$, HG: Homogenous groups have the same letter $(\mathrm{a}, \mathrm{b}$ and $\mathrm{ab}$ are different groups but $\mathrm{a}$ and $\mathrm{b}$ are significantly different), $n=$ Number of patients, $\mathrm{FBG}=$ Fasting blood glucose, $\mathrm{PPBG}=$ Post prandial blood glucose, HbA1c $=$ Glycated haemoglobin.

Table (3): Comparison among subjects with positive and negative PCR of lactobacillus acidophilus regarding liver enzymes.

\begin{tabular}{|c|c|c|c|c|}
\hline Variables & Measures & $\begin{array}{l}\text { NAFLD obese } \\
(\mathrm{N}=20)\end{array}$ & $\begin{array}{l}\text { NAFLD lean } \\
(\mathrm{N}=20)\end{array}$ & $\begin{array}{l}\text { Control } \\
(\mathrm{N}=20)\end{array}$ \\
\hline \multirow{3}{*}{$\begin{array}{l}\text { ALT } \\
(7-56) \\
\text { (IU/L) }\end{array}$} & Positive & $36.8 \pm 18.8$ & $28.9 \pm 10.9$ & $24.7 \pm 3.3$ \\
\hline & Negative & $35.2 \pm 23.5$ & $39.0 \pm 22.1$ & $25.3 \pm 4.0$ \\
\hline & $\wedge \mathrm{P}$ & 0.878 & 0.183 & 0.725 \\
\hline \multirow{3}{*}{$\begin{array}{l}\text { AST } \\
(10-40) \\
\text { (IU/L) }\end{array}$} & Positive & $33.2 \pm 12.2$ & $28.4 \pm 7.3$ & $25.8 \pm 6.4$ \\
\hline & Negative & $30.6 \pm 13.8$ & $33.7 \pm 13.0$ & $22.9 \pm 7.3$ \\
\hline & $\wedge \mathrm{P}$ & 0.694 & 0.262 & 0.352 \\
\hline \multirow{3}{*}{$\begin{array}{l}\text { GGT } \\
\text { (IU/L) } \\
(9-48)\end{array}$} & Positive & $21.4 \pm 5.0$ & $20.8 \pm 2.9$ & $21.5 \pm 5.5$ \\
\hline & Negative & $22.0 \pm 2.4$ & $19.7 \pm 3.0$ & $18.5 \pm 3.7$ \\
\hline & ${ }^{\wedge} \mathrm{P}$ & 0.803 & 0.448 & 0.194 \\
\hline
\end{tabular}

${ }^{\wedge}$ Independent t-test, ALT $=$ Alanine aminotransferase, AST $=$ Aspartate aminotransferase, GGT= Gamma glutamyl transferase. 
Table (4): Correlation between the cycle threshold PCR of lactobacillus acidophilus and variables in the NAFLD obese group.

\begin{tabular}{|l|c|c|c|c|c|c|}
\hline \multirow{2}{*}{ Variables } & \multicolumn{2}{|c|}{$\begin{array}{c}\text { All cases } \\
(\mathrm{N}=20)\end{array}$} & \multicolumn{2}{c|}{$\begin{array}{c}\text { Positive } \\
(\mathrm{N}=15)\end{array}$} & \multicolumn{2}{c|}{$\begin{array}{c}\text { Negative } \\
\text { (N=5) }\end{array}$} \\
\cline { 2 - 7 } & $\mathrm{r}$ & $\mathrm{p}$ & $\mathrm{r}$ & $\mathrm{P}$ & $\mathrm{r}$ & $\mathrm{p}$ \\
\hline Age $($ years) & -0.164 & 0.491 & -0.326 & 0.235 & -0.269 & 0.661 \\
\hline BMI $\left(\mathrm{kg} / \mathrm{m}^{2}\right)$ & 0.272 & 0.246 & 0.073 & 0.795 & -0.016 & 0.980 \\
\hline ALT $(\mathrm{IU} / \mathrm{L})$ & -0.078 & 0.744 & -0.077 & 0.785 & -0.098 & 0.876 \\
\hline AST $(\mathrm{IU} / \mathrm{L})$ & -0.064 & 0.787 & -0.010 & 0.972 & -0.013 & 0.984 \\
\hline GGT (IU/L) & -0.214 & 0.366 & -0.314 & 0.254 & -0.436 & 0.463 \\
\hline FBG (mg/dL) & 0.129 & 0.588 & 0.226 & 0.419 & -0.574 & 0.312 \\
\hline 2 hrs PPBG (mg/dL) & -0.190 & 0.422 & -0.252 & 0.365 & 0.276 & 0.653 \\
\hline HbA1c $(\%)$ & -0.166 & 0.484 & -0.365 & 0.181 & -0.678 & 0.208 \\
\hline S. total Cholesterol(mg/dL) & 0.076 & 0.750 & 0.139 & 0.622 & -0.144 & 0.817 \\
\hline S.Triglycerides (mg/dL) & 0.112 & 0.639 & 0.135 & 0.630 & -0.176 & 0.777 \\
\hline S. LDL Cholesterol (mg/dL) & 0.018 & 0.940 & 0.054 & 0.849 & -0.163 & 0.794 \\
\hline S. HDLCholesterol(mg/dL) & 0.284 & 0.225 & 0.415 & 0.124 & 0.200 & 0.748 \\
\hline
\end{tabular}

$\mathrm{r}=$ Pearson correlation Non-significant (N.S) if $\mathrm{P}>0.05$.

Significant (Sig) if $\mathrm{P}<0.05$. Highly significant (H.S) if $\mathrm{P}<0.001$

\section{DISCUSSION:}

Our study revealed significantly higher results among NAFLD obese patients compared to healthy control individuals, in terms of serum ALT and AST; total cholesterol, triglycerides, and LDL; FBG, two hours PPBG, and HbA1c. Moreover, higher HDL was found among healthy control individuals in comparison with NAFLD obese and NAFLD lean groups. These results were in line with the published clinical outcomes of both Chen et al. ${ }^{[19]}$ and Hung et $\mathrm{al}^{[20]}$. However, other studies showed no significant correlations between NAFLD patients and healthy controls concerning FBS, 2hrPP, HBA1C, LDL, and HDL ${ }^{[21,22]}$.

Interestingly, we found similar results among the included groups in terms of semiquantitative PCR results of lactobacillus acidophilus in the stool. Still, the NAFLD obese and NAFLD lean patients showed insignificantly higher lactobacillus acidophilus concentration in stool compared to the healthy control group, may be due semi quantitative method of detection .also it raises the suspicion that other species of lactobacilli and other microbiota may be involved in the development of NAFLD

Our results showed that insignificant elevation of transaminases in NAFLD obese group with positive PCR compared to other groups this was against Wong et al 2013 ${ }^{[23]}$ who found a beneficial role of lactobacillus acidophilus as probiotics with improvement of elevated liver enzymes

Still, there is a wide discrepancy between studies varying from an increased or decreased level of each type of gut microbiota in NAFLD patients [7,24-27]. Unlike study by Famouri et al $2017^{[28]}$ who found significant decrease in mean levels of ALT, AST in the group receiving lactobacillus acidophilus as probiotic medication in the treatment of obesity or NAFLD .

Our study showed that there was non significant difference as regard lipid profile and lactobacillus acidophilus, in contrast to animal study done by Huawei et al 2014 ${ }^{\text {[29] }}$ showed that high fat diet in eight out of 
twelve bacterial species that typically predominate hind gut microbial ecology were detected in fecal samples by DNA analysis. The DNA amount of one of these species, Lactobacillus (L.) acidophilus, was 6900-fold greater in high-fat fed mice compared to controls. Suggesting that L. acidophilus can promote inflammatory production of cytokines such as TNFa, which was also elevated in high-fat fed mice. These results suggest that changes in the hindgut microbiome which accompany high fat feeding may contribute to the development of steatohepatitis in obese mice unlike the above studies using lactobacillus acidophilus as a probiotics .

Noteworthy, the use of a semiquantitative PCR technique helped in giving a rough estimate for the concentration of the lactobacillus acidophilus between the study groups but did not show exact numbers for the microbiome levels.

Finally, the main limitation of this study was small number of the particibants and a limited area of recruitment, which might have affected the diversity of subjects and the significance of results. Also it was better to use the more accurate quantitative method of PCR for detection of lactobacillus acidophilus in stool

\section{Conflict of interest:}

The authors declare no conflict of interests.

We declare receiving no funds or grants for this study from any institution

\section{REFERENCES:}

1. Younossi ZM, Marchesini G, Pinto-Cortez $\mathrm{H}$, et al. Epidemiology of Nonalcoholic Fatty Liver Disease and Nonalcoholic Steatohepatitis: Implications for Liver Transplantation. Transplantation. 2019 Jan 1;103(1):22-7.

2. Alkassabany YM, Farghaly AG, El-Ghitany EM. Prevalence, risk factors, and predictors of nonalcoholic fatty liver disease among schoolchildren: A hospital-based study in Alexandria, Egypt. Arab J Gastroenterol. 2014;15(2):76-81.

3. Borai IH, Shaker Y, Kamal MM, Ezzat WM, Ashour E, Afify M, et al. Evaluation of Biomarkers in Egyptian Patients with Different Grades of Nonalcoholic Fatty Liver Disease. J Clin Transl Hepatol. 2017 Jun 28;5(2):109-18.

4. Smagris E, Basuray S, Li J, Huang Y, Lai KM V., Gromada J, et al. Pnpla3I148M knockin mice accumulate PNPLA3 on lipid droplets and develop hepatic steatosis. Hepatology. 2015 Jan 1;61(1):108-18.

5. Rooks MG and Garrett WS. Gut microbiota, metabolites and host immunity. Vol. 16, Nature Reviews Immunology. Nature Publishing Group; 2016. p. 341-52.

6. Jandhyala SM, Talukdar R, Subramanyam C, Vuyyuru H, et al. Role of the normal gut microbiota. World J Gastroenterol. 2015 Aug 7;21(29):8836-47.

7. Mouzaki M, Comelli EM, Arendt BM, Bonengel J, Fung SK, Fischer SE, et al. Intestinal microbiota in patients with nonalcoholic fatty liver disease. Hepatology. 2013 Jul;58(1):120-7.

8. Jasirwan COM, Lesmana CRA, Hasan I, Sulaiman AS, et al. The role of gut microbiota in non-alcoholic fatty liver disease: Pathways of mechanisms. Vol. 38, Bioscience of Microbiota, Food and Health. BMFH Press; 2019. p. 81-8.

9. Boursier J, Mueller O, Barret M, Machado M, Fizanne L, Araujo-Perez F, et al. The severity of nonalcoholic fatty liver disease is associated with gut dysbiosis and shift in the metabolic function of the gut microbiota. Hepatology. 2016 Mar 1;63 (3): 764-75.

10. Chalasani N, Younossi Z, Lavine JE, Charlton M, Cusi K, Rinella M, et al. The diagnosis and management of nonalcoholic fatty liver disease: Practice guidance from the American Association for the Study of Liver Diseases. Hepatology. 2018 Jan 1;67 (1): 328-57.

11. Heinz F and Beushausen TW. A New Enzymatic Method for the Determination of 
Glucose. Clin Chem Lab Med. 1981;19 (9):977-81.

12. Krolewski AS, Laffel LM b., Krolewski M, Quinn M, Warram JH, Krolewski AS, et al. Glycosylated hemoglobin and the risk of microalbuminuria in patients with insulindependent diabetes mellitus. N Engl J Med. 1995 May 11;332(19):1251-5.

13. Hyperlipoproteinemia. Prevalence in a freeliving population in Albany, New York. PubMed - NCBI [Internet]. [cited 2020 Jan 23]. Available from: https://www.ncbi.nlm. nih.gov/pubmed/4348123

14. Nakamura M, Yokoyama S, Kayamori Y, Iso $\mathrm{H}$, Kitamura $\mathrm{A}$, Okamura $\mathrm{T}$, et al. $\mathrm{HDL}$ cholesterol performance using an ultracentrifugation reference measurement procedure and the designated comparison method. Clin Chim Acta. 2015 Jan 5;439:185-90.

15. Mora S, Rifai N, Buring JE, et al . Comparison of LDL cholesterol concentrations by Friedewald calculation and direct measurement in relation to cardiovascular events in 27331 women. Clin Chem. 2009 May 1;55(5):888-94.

16. Dubernet S, Desmasures N, Guéguen M. A. PCR-based method for identification of lactobacilli at the genus level. FEMS Microbiol Lett. 2002 Sep 10;214(2):271-5.

17. Ezzat WM, Ragab S, Ismail NA, Elhosary YA, ElBaky AMNEA, Farouk $\mathrm{H}$, et al. Frequency of non-alcoholic fatty liver disease in overweight/obese children and adults: Clinical, sonographic picture and biochemical assessment. J Genet Eng Biotechnol. 2012 Dec 1;10(2):221-7.

18. Dasarathy S, Dasarathy J, Khiyami A, Joseph R, Lopez R, et al. Validity of real time ultrasound in the diagnosis of hepatic steatosis: A prospective study. J Hepatol. 2009 Dec;51 (6):1061-7.

19. Chen YM, Liu Y, Zhou RF, Chen XL, Wang C, Tan XY, et al. Associations of gut-flora-dependent metabolite trimethylamine- $\mathrm{N}$-oxide, betaine and choline with non-alcoholic fatty liver disease in adults. Sci Rep. 2016 Jan 8;6.

20. Hung CS, Tseng $\mathrm{PH}, \mathrm{Tu} \mathrm{CH}$, Chen $\mathrm{CC}$, Liao WC, Lee YC, et al. Nonalcoholic Fatty Liver Disease Is Associated With QT
Prolongation in the General Population. J Am Heart Assoc. 2015 Jul 21;4(7).

21. Grandinetti A, Chow DC, Miyasaki M, Low P. Association of increased QTc interval with the cardiometabolic syndrome. J Clin Hypertens. 2010 Apr; 12(4):315-20.

22. Käräjämäki $A J$, Pätsi $O P$, Savolainen $M$, Kesäniemi YA, et al . Non-alcoholic fatty liver disease as a predictor of atrial fibrillation in middle-aged population (OPERA study). PLoS One. 2015 Nov 1;10 (11).

23. Wong, V.W.; Won, G.L.; Chim, A.M.; Chu, W.C.; Yeung, D.K.; Li, et al . Treatment of nonalcoholicsteatohepatitis with probiotics. A proof-of-concept study.Ann. Hepatol. 2013,12, 256-262

24. Zhu L, Baker SS, Gill C, Liu W, Alkhouri $\mathrm{R}$, Baker RD, et al. Characterization of gut microbiomes in nonalcoholic steatohepatitis (NASH) patients: A connection between endogenous alcohol and NASH. Hepatology. 2013 Feb; 57(2):601-9.

25. Jiang W, Wu N, Wang X, Chi Y, Zhang Y, Qiu $X$, et al. Dysbiosis gut microbiota associated with inflammation and impaired mucosal immune function in intestine of humans with non-alcoholic fatty liver disease. Sci Rep. 2015 Feb 3;5.

26. Raman M, Ahmed I, Gillevet PM, Probert CS, Ratcliffe NM, Smith S, et al. Fecal microbiome and volatile organic compound metabolome in obese humans with nonalcoholic fatty liver disease. Clin Gastroenterol Hepatol. 2013;11(7):868875.e3.

27. Michail S, Lin M, Frey MR, Fanter R, Paliy $\mathrm{O}$, Hilbush $\mathrm{B}$, et al. Altered gut microbial energy and metabolism in children with non-alcoholic fatty liver disease. FEMS Microbiol Ecol. 2015 Feb 1;91(2):1-9.

28. Famouri F, Shariat Z, Hashemipour M, Keikha M, et al Effects of Probiotics on Nonalcoholic Fatty Liver Disease in Obese Children and Adolescents. JPGN. 2017, 64; 3.

29. Huawei Zeng, Jun Liu, Matthew Jackson, Lin Yan, et al , Fatty liver accompanies an increase of Lactobacillus acidophilus in the hind gut of C57/BL mice fed a high-fat diet, Nutrition, Apr 2013 


\title{
العلاقة بين اللاكتوباسيلاي (بكتيريا العصيات اللبنية)
}

\section{ومرض الكبد الدهني غير الكحولي في عينة من المصريين}

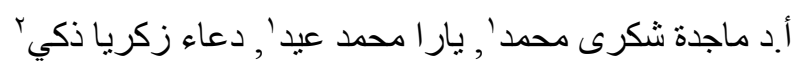

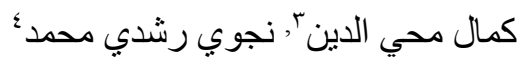

نبذة مختصرة : يحدث مرض الكبد الدهني الغير كحولي نتيجة لتر اكم الدهون الز ائدة في الكبد ويعتبر مرض الكي الكبد الكبد الأكثر

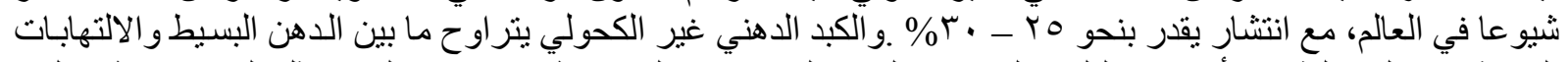

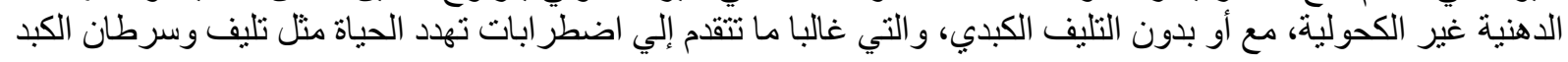

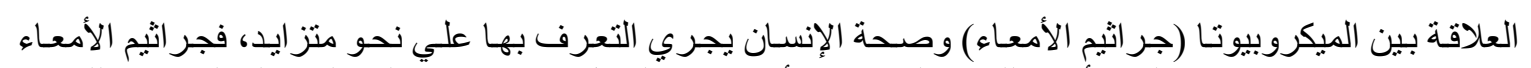

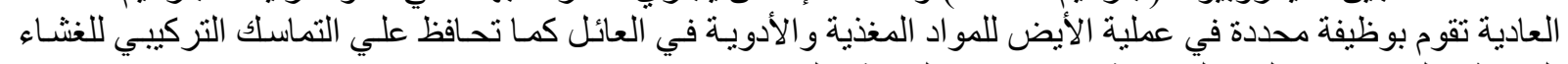

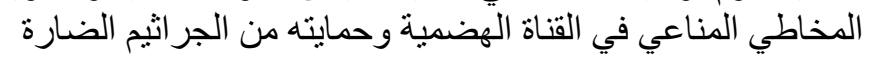

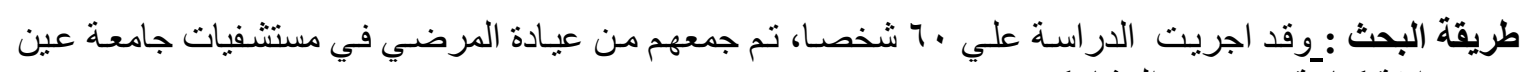

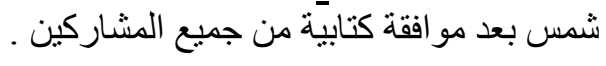

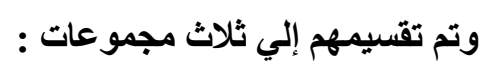

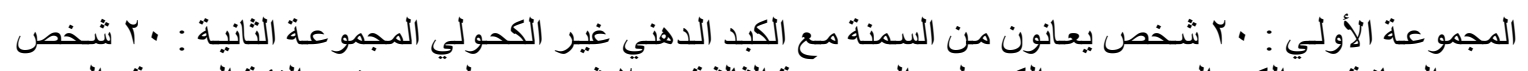

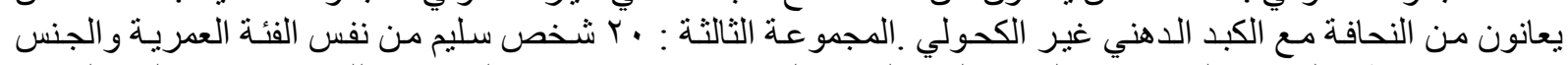

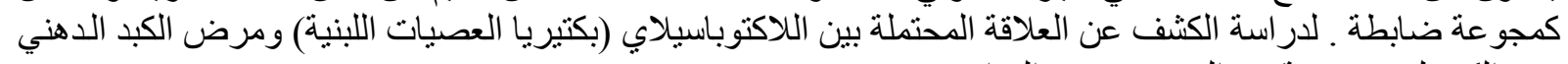
غير الكحولي في عينة من المصريين في البراز

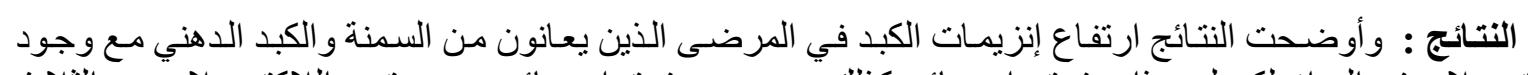

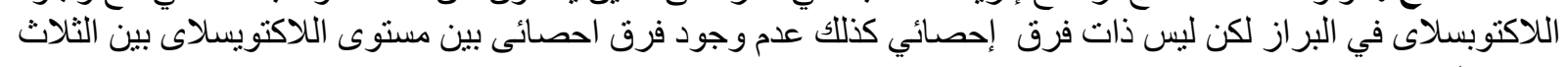
مجمو عات. 